\title{
The dramaturgy of gambang semarang art company (GSAC) a strategy towards tourism art
}

\author{
Damar Tri Afrianto ${ }^{\mathrm{a}, 1, *}$, Putut Bayu Santiko ${ }^{\mathrm{b}, 2}$ \\ a Program Studi Desain Komunikasi Visual Institut Teknologi Telkom Purwokerto, Indonesia \\ ${ }^{\mathrm{b}}$ Badan Otorita Borobudur, Yogyakarta, Indonesia \\ ${ }^{1}$ damar@ittelkom-pwt.ac.id*; ${ }^{2}$ bayputut@gmail.com \\ * corresponding author
}

ARTICLE INFO

Article history

Received 2021-06-03

Revised 2021-06-17

Accepted 2021-06-18

Keywords

Gambang Semarang

Tourism

Dramaturgy

The aesthetics of commercialism

\begin{abstract}
This research answers how the dramaturgical innovation of the Gambang Semarang Art Company (GSAC) performance is to go to tourism. The main objective is to explain GSAC's strategy in dealing with the tourism industry through dramaturgical innovation. This study uses a qualitative interpretive research method. Data were obtained through interviews and performance observations. The results showed that the Dadung Kepuntir story GSAC performance-inspired innovation and brought out new creativity. In addition, it gave rise to a form of presentation to enrich the repertoire of Gambang Semarang performances. The GSAC community is fully aware of the need for the arts for tourism. This can be seen from the approach to the show, which uses an aesthetic approach to commercialism. The aesthetics of commercialism is stated as the principles of managing the art forms of Gambang Semarang performed by the Gambang Semarang Art Company based on the attractiveness, fascination, and provocation of the attention of the mass audience of Gambang Semarang.
\end{abstract}

This is an open-access article under the CC-BY-SA license.

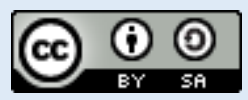

\section{Introduction}

Gambang Semarang as a traditional art cannot be separated from the changes and dynamics of the times. The existence of this art is required to continue to be adaptive in order to survive as sustainable art. The uniqueness of Gambang Semarang as an acculturative performing art between Javanese and Chinese cultures has its value as a treasure trove of knowledge, history, and aesthetic insights. Gambang Semarang, in its contestation with other modern performing arts, feels far removed. Especially during the New Order era, this art was interrupted by the government. After the new order, Gambang Semarang seemed to be reborn with various formats due to conservation and development work by the art-supporting community. Currently, Gambang Semarang as a work of art has a relatively good economic value, and this is a strategy that improves the community's welfare, mainly traditional artists. The development of traditional artworks into tourism destinations can allow Gambang Semarang artists to earn income from the tourism industry sector. The Indonesian government sees that the tourism industry will realize the community's welfare if it is worked on optimally. The Indonesian government has determined that 2016 is the year of accelerated acceleration to realize the achievement of development targets in each sector by targeting 12 million foreign tourist arrivals [1]. In 2018 the Indonesian government again placed the tourism industry in second place for the government's work plan program, meaning that now the Indonesian government wholly hopes that the tourism industry will contribute to foreign exchange to survive the country's economy [2]. Gambang Semarang, in this context, needs to be adjusted so that it can become part of the attractiveness of the tourism industry in Semarang. The problem is the strategy so that Gambang Semarang becomes one of the traditional arts that can become the leading art of tourism in the city of Semarang. About the above background, this research formulates how to innovate the dramaturgy of the Gambang 
Semarang performance to go to tourism. The main objective is to explain Gambang Semarang's strategy in dealing with the tourism industry through its dramaturgical innovations.

Several researchers have carried out research related to Gambang Semarang. Raharjo researched Gambang Semarang with a focus on cultural identity studies. The purpose of this study was to identify, describe, and analyze Semarang's participation in making Gambang Semarang music a cultural identity of the city of Semarang. This qualitative research resulted in the finding that the people of Semarang have a solid effort to realize the city's cultural identity through the music of Gambang Semarang. These efforts are realized through formal and non-formal education approaches, organizing festivals, workshops, discussions, and performances [3]. Research conducted by Azizah also examines the issue of Gambang Semarang; Azizah reveals the narrative problem built in the Gambang Semarang performance. The question posed is whether the Gambang Semarang performance narrates the multicultural spirit in the performance? In this study, Azizah concluded that Gambang Semarang narrated the multicultural society of Semarang. According to Azizah, this can be seen in the song Gambang Semarang, which has a multicultural background of people living in Semarang, namely Javanese, Kojan, and Chinese; besides, many musical instruments are used from different cultural backgrounds, such as combining various musical instruments. Javanese traditional musical instruments and the use of Chinese musical instruments [4]. Tonny Dian Effendi discusses local wisdom that contains tolerance between the Chinese community and other ethnicities in several places in Indonesia [5]. The topic of Gambang Semarang is also discussed in his research. Tony argues that discussions of ethnic Chinese issues are often associated with differences and stereotypes. According to him, these problems can be solved by using local wisdom strategies to grow tolerance values, one of which is seen in the Gambang Semarang performance. Tonny's research does not explicitly address the issue of Gambang Semarang in the context of tourism development, so there are weaknesses from the perspective of tourism development in the Gambang Semarang performance.

The results of research on Gambang Semarang that previous researchers have carried out indicate that the problem of Gambang Semarang in terms of the perspective of tourism development strategies has not yet been carried out; thus, this research has a real contribution to provide information on strategies for developing tourism based on performing arts. The phenomenon of the development of the culture-based tourism industry, especially traditional arts, is interesting to observe, considering that the Gambang Semarang arts, in particular, have the potential to be included in the tourism ecosystem, especially in the city of Semarang itself. The development of the tourism industry, which has now spread to all regions, has become a momentum for the rise of awareness about preserving cultural values in society. Tourism is considered to be an alternative industry that is capable of being a medium for preserving cultural values as well as a contributor to local revenue. The local government and the community are finally racing to make innovations to grow the arts and cultural tourism ecosystem. The development of the tourism industry is also felt by the arts community in preserving cultural heritage in the form of traditional arts. Tourism is expected to be a creative medium to support the existence of traditional arts. On the other hand, there is a concern that accompanies the development of art as a tourism product which is allegedly able to degrade the value of art itself. The transformation process will eventually cause new problems. Therefore, it becomes interesting to study related to the existence of the position of Gambang Semarang art in facing the development of the tourism industry.

\section{Method}

This study adopts a non-foundational ontological relativist position, namely that reality is multiple, fluid, and contextually dependent, and refers to a constructionist epistemological approach, namely that knowledge is socially constructed; meaning is subjective and relationally negotiated [6]. Based on this perspective, the data obtained from this research is viewed based on the surrounding context. In giving meaning to the data, a thorough understanding is carried out from various points of view so that the level of subjectivity can be suppressed [7]. Suppose data still has a high level of subjectivity. In that case, it is necessary to carry out a negotiation process and relate the data to other intersecting facts - data obtained through the stages of literature study, interviews, and documentation. Data regarding the dramaturgy of the Gambang Semarang performance, performance-based tourism policies get the main emphasis, this data is important to obtain information on government policies towards the development of performing arts-based tourism. Other data that needs to be obtained is the life data of Gambang Semarang, the data of the Gambang Semarang Art Company (GSAC) 
community which helps maintain the continuity of the musical life of Gambang Semarang. The data is used to analyze Gambang Semarang as a tourism art. This process is vital so that the conclusions obtained have a rational, logical, and solid argumentation basis. Figure 1 is the methodological stages in this research.

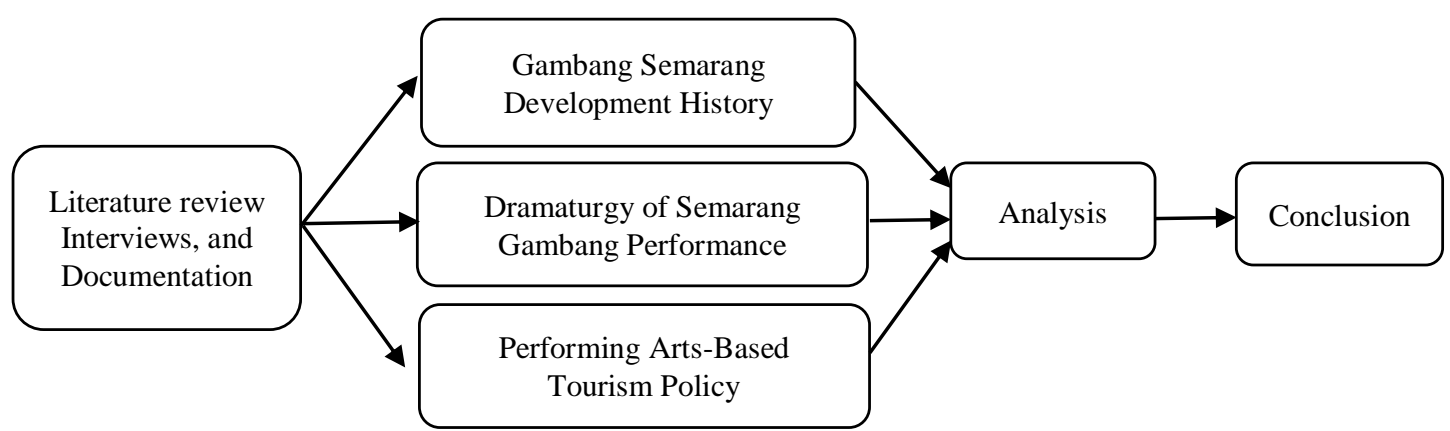

Fig. 1. Dramaturgy research method Gambang Semarang performance a strategy towards tourism art

\section{Results and Discussion}

\subsection{Gambang Semarang Development History}

Gambang is a traditional musical instrument consisting of wooden blades and is played by hitting it. This musical instrument is often used as part of Javanese and Betawi musical compositions [8]. The shape of the Gambang musical instrument is similar to the kulintang musical instrument, which is widely developed in Minahasa, North Sulawesi. One of the fundamental differences between the two musical instruments is using the laras (scale) in musical instruments. Gambang musical instruments in Java are more dominant using laras slendro or pelog. In other areas, the use of this instrument is often by using diatonic scales. In the art of Gambang Semarang, the Gambang musical instrument is the main part that must be present in this traditional art performance [9]. Gambang Semarang art originated from Gambang Kromong Jakarta, which a Chinese Chinese brought named Lie Hoo Soen (1898-1986) to Semarang [10]. Lie Hoo Soen is a central figure in the history of the development of Gambang Semarang in the early period [11]. This keroncong music fan is an administrator of the arts organization "Krido Hartojo" and was a member of the Volksraad (Dewan Perwakilan Rakyat) around 1930. Looking at the artistic needs of the city of Semarang, which at that time was dominated by Javanese art, Lie Hoo Soen had the idea to create a distinctive art Semarang city. The idea was discussed in the Council and then submitted to the Mayor of Semarang, whom Boesevain then occupied. Finally, the idea to create a typical Semarang art was approved by Boesevain. Lie Hoo Soen realized this by buying the musical instrument Gambang Kromong then conducting training and holding the first performance in 1932. Until now, the Gambang Semarang performances have continued, and the simple display combined with Javanese gamelan can be seen in Figure 2.

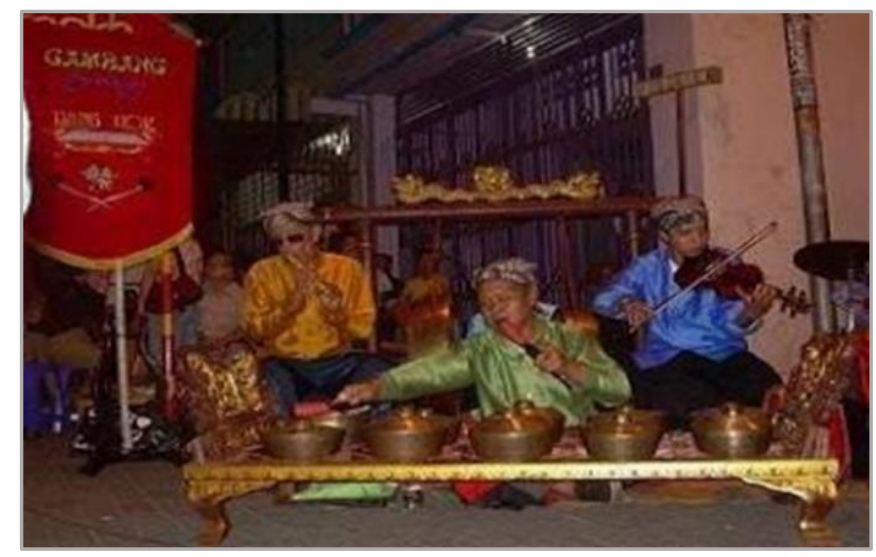

Fig. 2. Semarang Gambang Center Group Source: GSAC 2019

At the beginning of the appearance of Gambang Semarang, there were two types of the repertoire of songs contained in the Gambang Kromong tradition, namely the lagu lama and the lagu sayur [12]. 
Lagu lama is a Chinese song that is often presented at the beginning of Gambang Kromong's existence, consisting of old instrumental songs (phobins) and vocal songs [13]. The two types of old songs combine Chinese and Indonesian music [14], [15]. Meanwhile, the lagu sayur is a song in the form of vocals accompanied by music often performed in Gambang Kromong performances. Because it features Gambang Kromong songs, at first Gambang Semarang had musical characteristics similar to Gambang Kromong. However, the resemblance faded with the performance of memorable songs from Gambang Semarang, Central Javanese folk songs, keroncong songs, and Javanese pop songs [16]. At the beginning of the development of this music, the nuances of Betawi-Chinese and Javanese-Chinese are pretty strong. This is shown in the erhu performance or stringed instrument originating from China, as shown in Figure 3.

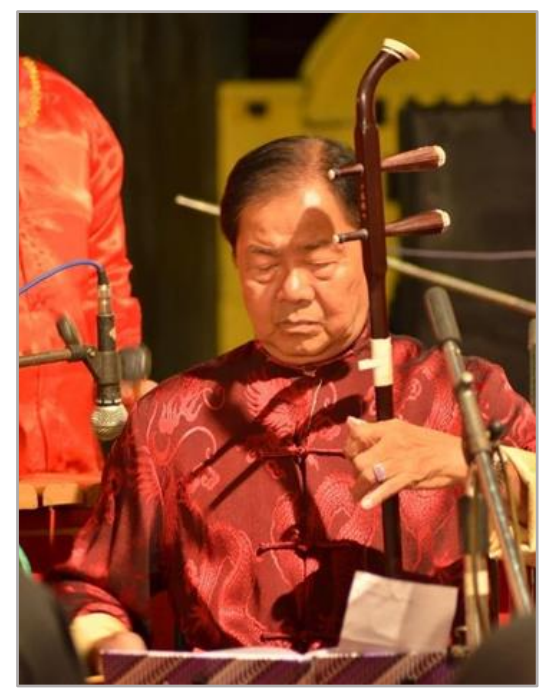

Fig. 3. Erhu Gambang Semarang Player Source: Doc. GSAC, 2020

In dance, Gambang Semarang has three basic movements, all of which are hip-centered, namely ngondhek, ngeyek, and genjot. Meanwhile, the hand movement (lambeyan) accompanying the three types of motion originates at the wrist, with the medium of motion limited to the navel to the eye [17]. The comedy (lawak) in Gambang Semarang has initially been just a singer's monologue, a dialogue between the singer and the musicians during a pause between one song and another or in between a song when it stopped (andhegan), and reciprocated rhymes performed by the singers. Thus, there was a need to perform comedy in development, which later became an inseparable element in the Gambang Semarang performance. There are three forms of jokes in Gambang Semarang: verbal jokes, nonverbal jokes, and musical jokes. Verbal jokes are made in monologue or dialogue; non-verbal jokes use gestures or body language, while musical jokes use musical instruments as accompaniment and support for a hilarious atmosphere. In terms of language, the comedy Gambang Semarang uses a mixture of Indonesian and Javanese and sometimes uses the Semarang dialect.

\subsection{The Form of Semarang Gambang Performance as a Tourism Product}

The meeting between Gambang Semarang arts and tourism was not planned as its primary objective was development and conservation. The tourism climate is the impact of the efforts of a community or art group that consciously and develops the art of Gambang Semarang. The results of several Gambang Semarang performances by GSAC, KGS, and an art studio managed by the Bintang Hanggoro Putra family were finally able to get the attention of the Regional Government to hold events or activities on a national scale, such as holding the Semarang Gambang Music Festival which is held every year. In addition, events related to the Semarang Gambang art began to emerge: Semarangan dance festival and activities in the form of scientific studies such as Semarang City art workshops that aim to socialize and bring the art of Gambang Semarang closer to the community that supports its arts. The Semarang City Government also includes the Gambang Semarang art festival into the calendar of events (COE) every year. The purpose of the inclusion of the festival in the COE is so that tourism stakeholders get standard information about events in Semarang City. From these events, Gambang Semarang can be seen as a tourism product. 
Placing the art of Gambang Semarang as a tourism product, in this case, is in line with the initial efforts to develop the traditional art of Gambang Semarang. The form of the Semarang Gambang Performance is not made rigid with specific standards like other traditional arts. The main point in this art is acculturative art by blending elements of Javanese culture with Chinese culture. Beyond that, the elements in it have the potential for renewal and contextual art today. In looking at the art form of Gambang Semarang about the position of Gambang Semarang as a tourism product, one of them can be analyzed through the Gambang Semarang performance which the Gambang Semarang Art Company group staged. Gambang Semarang Art Company, later abbreviated as GSAC, presented the Gambang Semarang art entitled Dadung Kepuntir, staged at Taman Indonesia Kaya Semarang on September 28, 2019. Gambang Semarang Art Company, often referred to by the acronym GSAC is one of the Gambang Semarang art communities born from community groups. This community is present as a form of awareness of the importance of preserving the traditional arts of Gambang Semarang. The initial idea of forming this community was initiated by people previously involved in Gambang Semarang, Undip Javanese Arts UKM. However, in its development, the GSAC group was finally able to become a joint forum between communities interested in the continuity of the Semarang Gambang art. The GSAC show with Dadung Kepuntir is a Gambang Semarang show funded by a private party (Figure 4). The performance emphasized the Gambang Semarang art encounter brought by the GSAC group with a more expansive stage with broader audience segmentation.

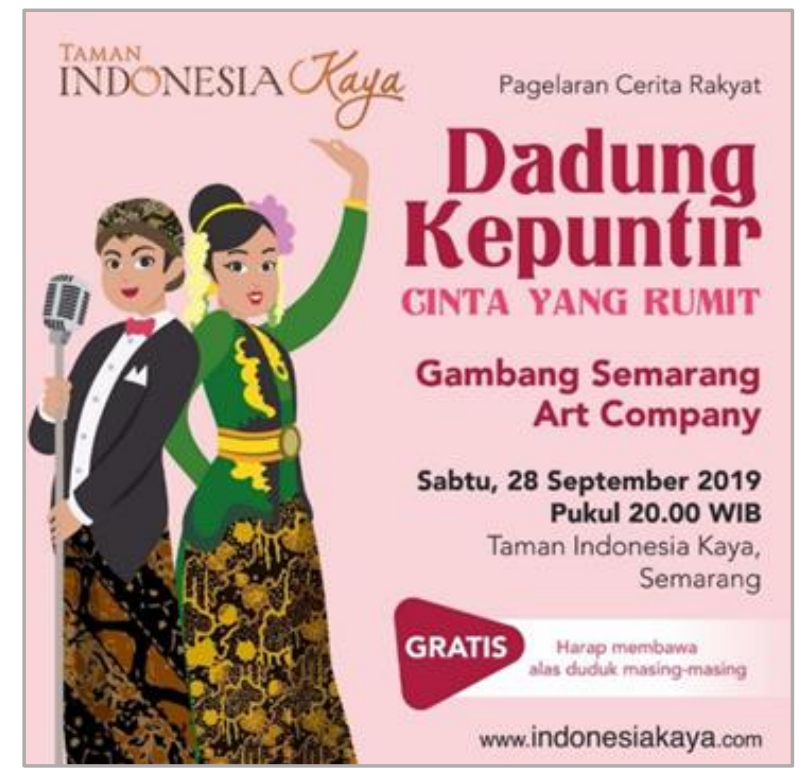

Fig. 4. GSAC Performance Poster

GSAC in the story Dadung Kepuntir is very well prepared with the composition of music, dance, and comedy that has been dramaturgically structured. GSAC seeks to develop the presentation of the Gambang Semarang performance by adjusting it to the audience segment. At that time, the audience at Taman Indonesia Kaya was an urban society consisting of a multicultural society, so that the performance approach by prioritizing commoditized aesthetics presented the concept of spectacle to satisfy the desires of the audience. This practice is closely related to the performing arts of tourism in general. However, on the other hand, because the character of Gambang Semarang art is still attached to traditional elements, especially Javanese and Chinese, so that apart from entertainment and spectacle, GSAC shows contain education, especially culture and history. Understanding the pattern of performance of this educational requirement is an important means of disseminating historical information to strengthen the position of Gambang Semarang as the city's identity. The audience, who are generally ordinary people, hopes that after seeing the Gambang Semarang performance, they will gain knowledge about the historical information contained in the story presented by GSAC. In addition, the presentation of Gambang Semarang also offers an offer to the audience to recall nostalgic memories about the art of Gambang Semarang. Usually, the old audience will miss the presentation of Gambang Semarang art as a form of nostalgia. Dadung Kepuntir is a folklore story that is closely related to the memory of the local community, especially the people of Central Java. 
The form of GSAC's performance in Dadung Kepuntir's story at Taman Indonesia Kaya is significant in terms of changes and developments due to market needs, especially the tourism market. GASAC's form of performance adopts the pattern of popular performing arts, where the presentation elements emphasize what trends are popular at that time. The novelty of this dish, according to Tri Subekso, is a strategic step to present a more creative Gambang Semarang by adjusting to the times. The initial scene opens with the Mberok Bridge setting; this scene is the show's opening scene, just like a show at the beginning is the introduction of the characters and the preparation of events as the story's opening. In the Dadung Kepuntir story, the scene presented is very thick, showing the prefix; in the dramatic structure, the part is termed exposition; this stage is an initial introduction that gives an overview to the audience about the events are being experienced by the characters. In the Dadung Kepuntir scene, the character Sumiyati enters the stage, walking to the stage while resentful because he waits for his girlfriend, Karyanto, who does not come. After Sumiyati opened with the prologue, the street buskers entered while laughing at Sumiyati alone until the music finished and the buskers came out. Humorous music, Karyanto came while riding a dirty/dilapidated motorbike/bike. Sumiyati was gloomy (angry) because Karyanto arrived so late, the atmosphere finally cleared up. They talked about the present and the past and were filled with music from the past. They both came out after the music finished. The opening gives the impression that the performance is highly articulated and that causality is clear.

The initial scene has a comedic nuance so that in the initial performance, the audience is presented with a surprise that makes laughter. The story about the city of Semarang is starting to be inserted; of course, this is part of the performance strategy that leads to identity; GSAC deliberately wants to bring its presentation closer to the reality of the audience's life. The audience will invite memories about the dynamics of the development of the city of Semarang so that the identity of Semarang is present as a form of reflection presented by GSAC. This opening part lasts until the next scene; The Handoyo character enters the stage carrying the dove's property while playing the male dove that the players fly with the aim that the male dove can land on the female dove game is called keplekan. People usually do Keplekan pigeons as a hobby. Then the character of Tasya entered after the song Tanjung Mas performed by GSAC musicians. The scene continues when Handoko sees Tasya from a distance and falls in love with her. Handoko expresses feelings to Tasya, the change of atmosphere is continued by the song Bunga Anggrek. The plot then enters the complication stage; problems begin to appear at this stage, and problems become complex and complicated. This stage is seen when a new character, namely Karyanto, enters the house in a confused state, then calls for Handoko. Handoko enters and gets scolded by Karyanto, and they fight each other. Finally, Handoko left the house, Tasya entered into trouble with her relationship with Handoko. Handoko enters, Tasya disconnects. This scene marked the climax of the Dadung Kepuntir show hosted by GSAC. GSAC chose the controversy about love because the audience who watched this show had memories that everyone had experienced. This strategy is quite famous for dealing with romance issues that the audience will more readily accept.

The tourism industry and the arts are two things that can synergize in efforts to develop regional development. Many challenges indeed traverse the synergism of the two. Various efforts must be made to establish cooperation between art and tourism, but sometimes the function of art is only used as entertainment. This paper proposes some critical thinking or strategic formulations of art and tourism based on the analysis and study of the GSAC story Dadung Kepuntir performance. The GSAC show is considered successful in offering art with tourism segmentation, which is entertainment, attracts the audience, especially tourists, and provides an aesthetic experience through solid local values. These strategies include; (1) the presentation of Multi-disciplinary Art and Innovative packaging; (2) art collaboration with the concept of tourism; (3) extracting local wisdom as an effort to get an aesthetic experience for tourists. Arts and tourism require a strategy that continues to develop, as does the tourism industry, which is constantly evolving. Therefore, many art studies on tourism must be done and paid attention to find new and relevant strategies. So it is hoped that this strategy will become the initial basis for developing art as an effective, innovative, and cultured tourism promotion medium. Figure 5 is a form of Gambang Semarang performance from a tourism perspective, with a magnificent, attractive, modern appearance. The climax occurs when Tasya and Karyanto compliment each other on Tasya's beauty and Karyanto's bravery. In the end, Tasya and Karyanto fell in love with the song Bersuka Ria and Berdansa Asik berdansa. At that time, Sumiyati entered as another character in this performance; Handoko then met with Tasya and Karyanto. The next scene is then angry with each other for having an affair. There was a conflict between them which 
culminated in a fierce battle. The climax scene was closed with the resolution of the dispute by his friend Karyanto. Then the scene continued with the appearance of dancers and music as the closing of the Gambang Semarang performance entitled Dadung Kepuntir, which Gambang Semarang Art Company performed. The scenes in the GSAC performance are interspersed with some music and dance, sometimes overlapping with the comedy-drama. GSAC brings Dadung Kepuntir's story as a contemporary musical drama performance that considers today's contextual. It can be seen from the several choices of music presented, GSAC deliberately includes popular songs at this time.

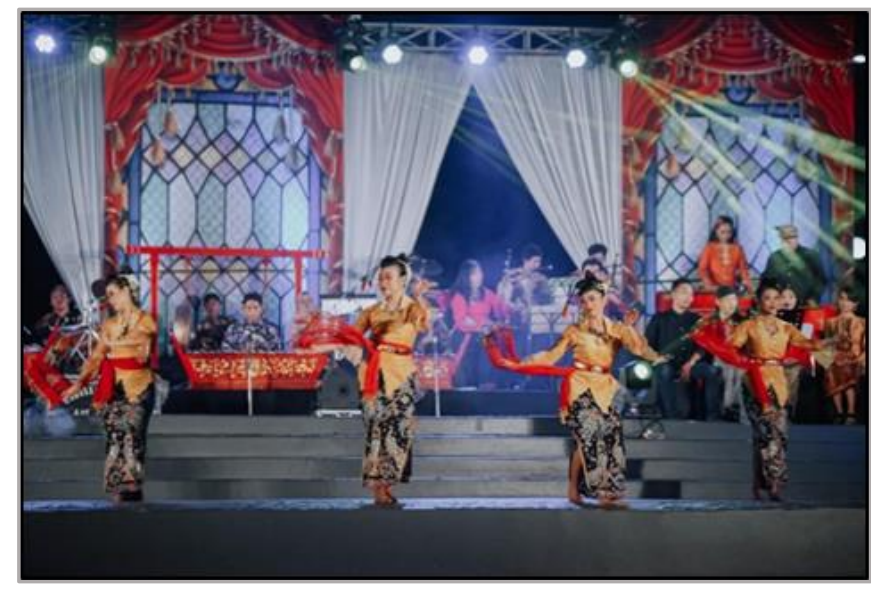

Fig. 5. GSAC Dadung Kepuntir Story Performance Source: Doc. GSAC 2019

However, on the other hand, the popular nuance is thick; the presence of musical instruments and their arrangements still brings out the nuances of Javanese-Chinese acculturation that characterizes the art of Gambang Semarang. Popular songs such as Pamer Bojo by Didi Kempot are presented with the nuances of Javanese-Chinese acculturation music. In this performance, contemporary performing arts can be found, combining traditional art and modern/pop art. The mix of pop material in the Dadung Kepuntir performance becomes a novelty nuance to follow the rhythm of the audience so that the display does not become monotonous. The presence of Dance in the GSAC performance dominates the structure of the performance. The Gambang Semarang dance emerged as a scene transition, also able to stand alone technically. Dance is explored further by incorporating modern elements to strengthen each scene. In addition, the Gambang Semarang dance is also present as a traditional dance as the artistic identity of Gambang Semarang. The Dadung Kepuntir story performance has an awareness of processing dance works, from traditional to modern creations. The GSAC performance, Dadung Kepuntir, was closed with a colossal dance performed together with the audience. All the scenes in this story lead to the closing dance presentation. Just like popular performing arts, at the end of the festivities, space is poured out to give the impression of glamorous performance. The lighting mingled with music closed the GSAC performance with the story Dadung Kepuntir. Crowded cheers and applause from the audience echoed when the players came forward to close the performance, as shown in Figure 6.

That night, the GSAC performance was a success with a booming audience. Spectators from all walks of life gathered in the middle of the city park to watch traditional arts rarely encountered every day. Small children, adults, to parents are fun and immersed in every scene that the GSAC art group displays. The packaging of the performance is designed to enter the layers of the Semarang city community without leaving the multicultural value as the identity of the city of Semarang. This is a good precedent for the preservation of traditional arts such as Gambang Semarang. GSAC can answer concerns about the continuity of this art with novel formulations that prioritize the value of acculturation and education in every performance. The theme of romance becomes the central theme which then adds romance to the audience. They can reminisce about the beautiful memory of Semarang's existence as a city that has specific memories. GSAC puts on a show full of local values in the Dadung Kepuntir performance. This locality can be seen from the comedian dialect, the show's setting, which involves many famous places in Semarang such as the Jembatan Berok, Kota Lama, Lawang Sewu, etc. In addition, the narrative built on the performance brings the audience's 
imagination to dissolve in the atmosphere of the city of Semarang. Social practices that are close to the community are displayed at the GSAC Dadung Kepuntir performance.

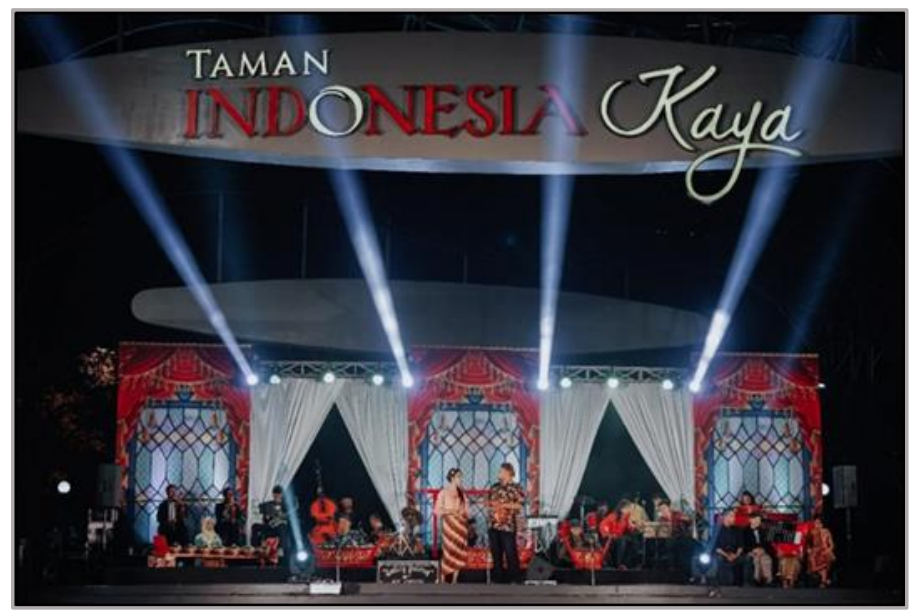

Fig. 6. Main Character Dadung Kepuntir GSAC Source: Doc. GSAC, 2019

The Gambang Semarang GSAC performance with the story of Dadung Kepuntir, which was staged in an opera-like format, gave the audience a new feel. The show's location, which is right in the center of Semarang, is a reminder for every citizen of the city to continue to care about the continuity of their traditional arts. Tri Subekso, as the performance committee, said that the show that night was very successful, as seen from the enthusiasm of the audience who followed the storyline carefully from beginning to end. This is a good sign when Gambang Semarang is present in the life of the Semarang people. In addition, the opportunity for the performance is interpreted as a form of klangenan (romanticism) in the past for the existence of Gambang Semarang art. The performance's concept finally confirmed the existence of GSAC, which became an independent community with the spirit of diversity and the mission of the spirit of hybrid folklore inherent in this community. Based on the analysis of the form of the GSAC performance with the story of Dadung Kepuntir above, an understanding can be drawn that the art of Gambang Semarang can become an art related to the tourism industry. This has been proven when the GSAC arts group presented Gambang Semarang with the story of Dadung Kepuntir through a famous performing arts approach. Popular performing arts are interpreted as a performance where the main character is an element of commercialism, seen in Table 1. GSAC, through the play Dadung Kepuntir presents performances with the aesthetics of commercialism, the aesthetics of commercialism are stated as the principles of managing forms based on attractiveness, fascination, and provocation of the attention of the consumer masses, the audience is spoiled with entertainment that arouses the desire for aesthetic practice without having to think hard to understand it [18]. With this approach, Gambang Semarang can work together in the tourism industry, both as a cultural tourism commodity and a form of tourism attraction.

Table 1. Dramaturgy structure GSAC

\begin{tabular}{|c|c|}
\hline \multicolumn{2}{|c|}{ Performance Dramaturgy GSAC } \\
\hline Structure Performance & the aesthetics of commercialism \\
\hline $\begin{array}{l}\text { the presentation of Multi-disciplinary Art and Innovative } \\
\text { packaging }\end{array}$ & $\begin{array}{l}\text { principles of managing forms based on } \\
\text { attractiveness }\end{array}$ \\
\hline art collaboration with the concept of tourism & fascination \\
\hline $\begin{array}{c}\text { extracting local wisdom as an effort to get an aesthetic } \\
\text { experience for tourists }\end{array}$ & $\begin{array}{l}\text { provocation of the attention of the } \\
\text { consumer masses }\end{array}$ \\
\hline & $\begin{array}{l}\text { the audience is spoiled with } \\
\text { entertainment that arouses the desire for } \\
\text { aesthetic practice without having to } \\
\text { think hard to understand it }\end{array}$ \\
\hline
\end{tabular}

GSAC can provide Gambang Semarang traditional art creations into performances that have the flexibility and contextual patterns. The dominant aspect of entertainment in this art is still inserting 
tradition as an added value displayed by the GSAC community to conserve and develop the art of Gambang Semarang. As an acculturative performing art between Javanese and Chinese cultures, Gambang Semarang through the GSAC group appears as a modern performing art that removes the bias of racial differences between the two. All are united in a presentation that is close to the community and interacts with the audience. Ethnic boundaries built by the political climate of the past do not seem to exist when all components are united in a Gambang Semarang performance. GSAC has succeeded in packaging the traditional art of Gambang Semarang into a force for the development of Gambang Semarang art in a more popular direction so that all circles can accept it. The Gambang Semarang GSAC art group can process traditional folklore that is part of the community as a form of performance presentation. This elaborative and collaborative ability has more value in the performing arts of tourism because tourism always cultivates the uniqueness of an area or community, which then becomes the main attraction for the development of Gambang Semarang. The tourism industry requires an element of uniqueness in each of its products. This becomes important in relating the traditional art of Gambang Semarang as a tourism product.

\section{Conclusion}

The Dadung Kepuntir performance displayed by GSAC has a structure and form that is adaptive to the performing arts of tourism. Flexibility in this art performance pattern is capital and, at the same time, an essential requirement informing an art and culture-based tourism ecosystem. Gambang Semarang, through the GSAC performance, can become a tourism commodity by bringing a multicultural message with an aesthetic approach to commercialism. The aesthetic concept of commercialism is a strategy for GSAC performances to introduce the form and idea of the Gambang Semarang performance in a tourism format as a form of support for the city of Semarang as a multicultural city.

\section{References}

[1] J. W. Lee and A. M. Syah, "Economic and Environmental Impacts of Mass Tourism on Regional Tourism Destinations in Indonesia," J. Asian Financ. Econ. Bus., vol. 5, no. 3, pp. 31-41, Aug. 2018, doi: 10.13106/jafeb.2018.vo15.no3.31.

[2] S. Purnomo, E. S. Rahayu, A. L. Riani, S. Suminah, and U. Udin, "Empowerment Model for Sustainable Tourism Village in an Emerging Country," J. Asian Financ. Econ. Bus., vol. 7, no. 2, pp. 261-270, Feb. 2020, doi: 10.13106/jafeb.2020.vol7.no2.261.

[3] E. Raharjo and U. Arsih, "Gambang Semarang Music as A Cultural Identity Of Semarangs Community," in Proceedings of the 2nd International Conference on Arts and Culture (ICONARC 2018), 2019, doi: 10.2991/iconarc-18.2019.62.

[4] R. C. Azizah, S. Edelweiss, and A. Riyandari, "Representing Multicultural Semarang through Gambang Semarang's Narrative," Celt A J. Cult. English Lang. Teach. Lit., vol. 18, no. 2, p. 248, Dec. 2018, doi: 10.24167/celt.v18i2.1300.

[5] T. D. Effendi, "Local Wisdom in Tolerance Building between Ethnic Chinese and Other Ethnics in Indonesia," in Proceedings of the 2nd International Conference on Arts and Culture (ICONARC 2018), 2019, doi: 10.2991/iconarc-18.2019.104.

[6] A. C. Sparkes and B. Smith, "Judging the quality of qualitative inquiry: Criteriology and relativism in action," Psychol. Sport Exerc., vol. 10, no. 5, pp. 491-497, Sep. 2009, doi: 10.1016/j.psychsport.2009.02.006.

[7] K. R. McGannon, B. Smith, K. Kendellen, and C. A. Gonsalves, "Qualitative research in six sport and exercise psychology journals between 2010 and 2017: An updated and expanded review of trends and interpretations," Int. J. Sport Exerc. Psychol., vol. 19, no. 3, pp. 359-379, May 2021, doi: 10.1080/1612197X.2019.1655779.

[8] C. D. Grijns, "Lenong in the environs of Jakarta : a report," Archipel, vol. 12, no. 1, pp. 175-202, 1976, doi: 10.3406/arch.1976.1301.

[9] S. Sunarto, I. R. H. Sejati, and U. Utomo, "Mimicry and Hybridity of 'Congrock Musik 17' in Semarang," Harmon. J. Arts Res. Educ., vol. 20, no. 1, pp. 29-38, 2020, doi: 10.15294/harmonia.v20i1.24563. 
[10] E. Heins, "Kroncong and Tanjidor - Two Cases of Urban Folk Music in Jakarta," Asian Music, vol. 7, no. 1, p. 20, 1975, doi: 10.2307/833924.

[11] P. Yampolsky, "Three Genres of Indonesian Popular Music: Genre, Hybridity, and Globalization, 19602012," Asian Music, vol. 44, no. 2, pp. 24-80, 2013, doi: 10.1353/amu.2013.0018.

[12] B. Wiryomartono, "Batavia, Dutch Indies 1602-1800: A Cultural History of Colonial Urbanism," in Traditions and Transformations of Habitation in Indonesia, Singapore: Springer Singapore, 2020, pp. 57-79. doi: 10.1007/978-981-15-3405-8_4

[13] M. I. Cohen, "On the origin of the Komedie Stamboel. Popular culture, colonial society, and the Parsi theatre movement," Bijdr. tot taal-, land- en Volkenkd. / J. Humanit. Soc. Sci. Southeast Asia, vol. 157, no. 2, pp. 313-357, 2001, doi: 10.1163/22134379-90003811.

[14] B. N. Setiawan, "Cina Benteng: The Latest Generations and Acculturation,” Ling. Cult., vol. 9, no. 1, p. 35, May 2015, doi: 10.21512/lc.v9i1.759.

[15] J. Knörr, “'Free the dragon' versus 'Becoming Betawi': Chinese identity in contemporary Jakarta 1," Asian Ethn., vol. 10, no. 1, pp. 71-90, Feb. 2009, doi: 10.1080/14631360802628467.

[16] N. Natalia and A. Riyandari, "Gambang Semarang: The Spirituality of Simple Accustomed Belief in Seemingly Far-fetched Culture," in The 2nd International Seminar on Educational Technology 2016, 2016, p. 62. Available at: Google Scholar.

[17] L. Paranti, D. Zustiyantoro, and K. Kumala, "The Adaptation Strategy of Semarangan Dance Style's Learning Method in UNNES during Covid-19 Pandemic Era," in Proceedings of the 2nd International Conference on Progressive Education, ICOPE 2020, 16-17 October 2020, Universitas Lampung, Bandar Lampung, Indonesia, 2021, doi: 10.4108/eai.16-10-2020.2305203.

[18] D. N. Coury, "From Aesthetics to Commercialism: Narration and the New German Comedy," Semin. A J. Ger. Stud., vol. 33, no. 4, pp. 356-373, Nov. 1997, doi: 10.3138/sem.v33.4.356. 